\title{
PENGARUH PENGGUNAAN GADGET TERHADAP KONSENTRASI BELAJAR SISWA DI SMA NEGERI 6 PRABUMULIH
}

\author{
Tia Adelia ${ }^{1}$, Taty Fauzi $^{2}$, Arizona ${ }^{3}$ \\ Universitas PGRI Palembang ${ }^{1}$ \\ Email : tiaadelia071@gmail.com \\ Universitas PGRI Palembang ${ }^{2}$ \\ Email: taty.fauzi@mail.com \\ Universitas PGRI Palembang ${ }^{3}$ \\ Email : arizona.karno@gmail.com
}

\begin{abstract}
ABSTRAK
Tujuan dari penelitian ini mengetahui apakah ada pengaruh penggunaan gadget terhadap konsentrasi belajar siswa di SMA Negeri 6 Prabumulih. Penelitian ini dilakukan dengan menggunakan metode survei dengan pendekatan kuantitatif, data yang didapatkan berasal dari angket yang disebarkan kepada responden (siswa) kelas XI IPA 1 dan siswa kelas XI IPS 1 dengan jumlah sampel 42 orang siswa dengan pengambilan sampel menggunakan rumus Slovin dan pengambilan jumlah sampel setiap kelas menggunakan rumus Propotional Random Sampling. Hasil dari penelitian ini menjelaskan bahwa ada pengaruh penggunaan gadget terhadap konsentrasi belajar siswa di SMA Negeri 6 Prabumulih dengan $t_{\text {hitung }}=8,63>t_{\text {tabel }}=1,68385$ dengan koefisien determinasi pengaruh penggunaan gadget terhadap konsentrasi belajar sebesar 67\% dan 33\% sisanya dipengaruhi oleh faktor lain yang tidak diteliti oleh peneliti dalam penelitian ini.
\end{abstract}

Kata Kunci: Gadget, Smartphone, Konsentrasi Belajar

\section{THE EFFECT OF GADGETS USE ON THE CONCENTRATION OF STUDENTS'S IN SENIOR HIGH SCHOOL 6 PRABUMULIH}

\begin{abstract}
This occurs due to a lack of understanding of the wise use of gadgets by students, which causes student concentration to become divided on the gadget (smartphone) they are using. This study aims to determine whether there is an effect of the use of gadgets on student concentration in SMA Negeri 6 Prabumulih. This research was conducted using a survey method with a quantitative approach, the data obtained came from a questionnaire distributed to respondents (students) class XI IPA 1 and class XI IPS 1 students with a total sample of 42 students by taking the sample using the Slovin formula and taking the number of samples. each class uses the proportional random sampling formula. The results of this study explain that there is an effect of the use of gadgets on the learning concentration of students at SMA Negeri 6 Prabumulih with tcount $=8.63>$ ttable $=1.68385$ with the coefficient of determination of the effect of using gadgets on
\end{abstract}


learning concentration by $67 \%$ and the remaining $33 \%$ is influenced by factors others that were not examined by researchers in this study.

\section{Keywords: Gadgets,Smartphones,Learning Concentration}

\section{PENDAHULUAN}

Pada era millenial teknologi sudah sangat berkembang pesat, dan sangatberpengaruh bagi kehidupan manusia, keberadaan dan perkembangan teknologi merupakan salah satu hal yang tidak bisa di tolak oleh manusia. Perubahan zaman muncul seiring dengan kemajuan teknologi yang diciptakan manusia, semakin canggih teknologi maka akan semakin besar pengaruhnya terhadap individu diseluruh dunia dan semakin banyak individu yang ingin mempunyai dan ingin bisa menguasai kecanggihan teknologi. Ada beragam jenis teknologi, dan salah satu teknologi yang sangat berpengaruh dan hampir dimiliki

oleh setiap individu mulai dari usia anakanak sampai dengan usia orang dewasa adalah Gadget.

Gadget adalah sebuah istilah yang berasal dari bahasa inggris, yang artinya perangkat elektronik kecil yang memiliki fungsi khusus. Dalam bahasa indonesia, gadget disebut sebagai 'acang'. Taty dan Melinda (2020).

Gadget merupakan suatu alat teknologi yang saat ini berkembang pesat yang memiliki fungsi khusus diantaranya yaitu smartphone, I phone, Blackberry, komputer, laptop, notebook, tab, dan lain-lain. Gadget adalah barang canggih yang diciptakan serta memiliki berbagai aplikasi yang dapat menyajikan berbagai jejaring sosial, media berita, hobi, ataupun hiburan, Manumpil, et al (2015:1).

Gadget sebagai benda dengan karakteristik unik, memiliki sebuah unit dengan kinerja yang tinggi dan berhubungan dengan ukuran serta biaya." Salah satu hal yang membedakan lainnya adalah unsur 'kebaruan' . Artinya, dari hari ke hari, gadget selalu muncul dengan menyajikan teknologi terbaru yang membuat hidup manusia menjadi lebih praktis.gadgetdengan perangkat elektronik, Rayner (dalam Anggraeni dan Hendrizal, 2018: 66).

Selanjutnya menurut Witarsa, dkk (2018: 12) menjelaskan bahwa "Gadget adalah media yang dipakai sebagai alat komunikasi modern.Gadget adalah perangkat elektronik kecil yang memiliki fungsi khusus”. Jenis elektronik kecil 
(gadget) yang lebih banyak digunakan dan mudah untuk dibawa kemana-mana ialah telepon genggam (smartphone).

\section{LANDASAN TEORI}

Smartphone berasal dari bahasa Inggris yang terdiri dari dua kata yaitu smart dan phone. Smart berarti pintar sedangkan phone berarti telepon.Sementara secara istilah smartphone telepon seluler yang mempunyai kemampuan seperti PC (personal computer).Dengan fungsinya tersebut, smartphone dapat dianggap sebagai komputer mini yang berbentuk telepon genggam.Smartphonedijalankan dengan bantuan sistem operasi, beberapa diantaranya seperti iPhoneOS, Android, Windows Phone, RIMBlackberry, Rahayu (2015: 10).

Menurut Intan, dkk. (2017: 5) "Smartphone adalah telepon genggam yang mempunyai kemampuan dengan pengunaan dan fungsi yang menyerupai komputer.Belum ada standar pabrik yang menentukan arti smartphone.Bagi beberapa orang, smartphone merupakan telepon yang bekerja menggunakan seluruh perangkat lunak sistem operasi yang menyediakan hubungan standar dan mendasar bagi pengembang aplikasi.

Menurut Gary b, dkk. (dalam saiful, 2016:101) “smartphone adalah telepon yang bisa dipakai internetan yang biasanya menyediakan fungsi Personal Digital Assistant (PDA), seperti fungsi kelender, buku agenda, buku alamat, kalkulator, dan catatan”. Banyaknya manfaat pada smartphone yang bisa digunakan oleh penggunanya kapanpun dan dimanapun membuat siswa sering menggunakan smartphone dengan kurang bijak seperti mengaplikasikan smarphone pada saat jam belajar sehingga menyebabkan konsentrasi belajar siswa terganggu.

Konsentrasi belajar adalah suatu aktivitas untuk membatasi ruang lingkup perhatian seseorang pada satu objek atau satu materi pelajaran, Benjamin (dalam Nuryana dan Purwanto 2010: 91).

Konsentrasi belajar merupakan kemampuan memusatkan perhatian pada pelajaran. Pemusatan perhatian tersebut tertuju pada isi bahan belajar maupun proses memperolehnya, Dimyati dan Mudjiono (dalam setiani, 2014: 17).

Ikawati (2016: 159) menyatakan bahwa "Konsentrasi belajar merupakan pemusatan daya pikiran dan perbuatan pada suatu objek yang dipelajari dengan 
menghalau atau menyisihkan segala hal yang tidak ada hubungan dengan objek yang dipelajari”. Konsentrasi belajar sangat mudah terganggu apabila siswa tidak benar-benar memfokuskan pikirannya pada apa yang sedang di pelajari oleh siswa, banyaknya hal yang bisa mengganggu konsentrasi belajar siswa pada saat jam pelajaran berlangsung seperti bermain gadget (smartphone) pada saat guru sedang menjelaskan materi pelajaran yang akan di bahas, menyalahgunakan penggunakan gadget (smatphone) yang tadinya guru menyuruh siswa untuk membuka internet mencari materi yang sedang dibahas di internet tetapi siswa malah menggunakan gadget (smartphone) untuk membuka aplikasi lain yang ada pada gadget seperti media sosial ataupun game.

Fenomena ini yang terjadi di SMA Negeri 6 Prabumulih, dimana terdapat siswa yang menyalahgunakan penggunaan gadgetpada saat jam pelajaran di kelas. Beberapa siswa tersebut mengunakan gadget (smartphone) untuk membuka aplikasi media sosial pada saat jam pelajaran berlangsung padahal guru yang sedang mengajar pada saat itu menyuruh siswa mengaplikasikan gadget (smartphone) untuk membuka internet dan mencari materi lainnya yang berkaitan dengan materi pelajaran yang sedang di bahas pada saat itu. Berdasarkan fenomena yang terjadi maka peneliti melakukan penelitian dengan judul "Pengaruh PenggunaanGadget Terhadap Konsentrasi Belajar Siswa Di SMA Negeri 6 Prabumulih".

\section{METODE PENELITIAN}

Penelitian ini merupakan penelitian kuantitatif dengan desain survei. Langkah yang dilakukan oleh peneliti untuk mengumpulkan data dalam penelitian ini sebagai berikut : pertama peneliti membuat angket penelitian dengan butir pernyataan yang sesuai dengan apa yang akan diteliti, lalu peneliti menguji kevaliditasan setiap butir angket yang akan peneliti ujikan kepada responden, setelah itu peneliti menyebarkan angket penelitian kepada responden dengan sampel yang telah peneliti tentukan, setelah semua angket penelitian tersebar dan diisi oleh responden barulah peneliti menghitung data yang peneliti dapatkan dari angket tersebut. 


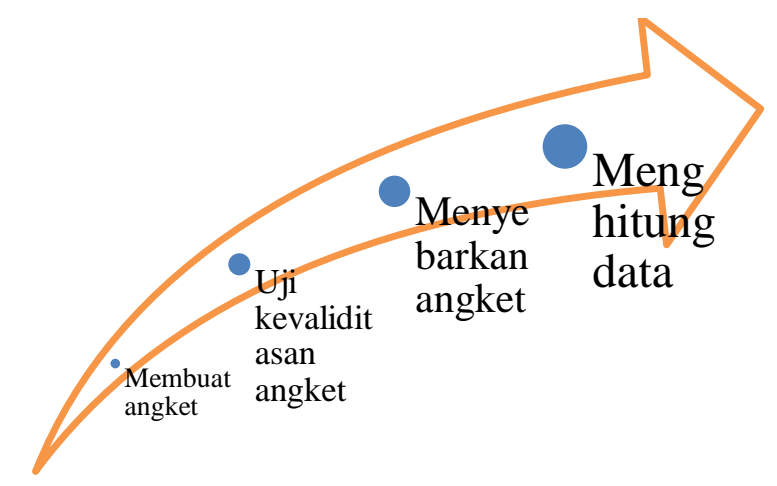

\section{Gambar 1. Langkah pengumpulan data}

1. Populasi

Populasi adalah wilayah generasi yang terdiri atas objek atau subjek yang mempunyai kualitas dan karakteristik tertentu yang ditetapkan oleh peneliti untuk dipelajari dan kemudian ditarik kesimpulannya yang tepat, Sugiyono (2018 : 177). Berdasarkan pengertian diatas maka populasi dalam penelitian ini adalahsiswa kelas XI IPA 1 dan XI IPS 1 SMA Negeri 6 Prabumulih dengan jumlah 72 orang siswa (responden).

2. Sampel

Menurut Sugiyono (2018:118) "Sampel merupakan sebagian dari jumlah dan karakteristik yang dimiliki oleh populasi. Peneliti tidak mungkin mengambil sampel pada seluruh populasi karena keterbatasan waktu, dana, dan tenaga".

Sampel penelitian adalah sebagian yang diambil dari keseluruhan objek yang diteliti dan dianggap mewakili seluruh populasi.Dalam menghitung besarnya sampeldapat menggunakan rumus Slovin menurut Sugiyono (dalam Zahrah, $2018: 33)$.

$$
\mathrm{n}=\frac{N}{1+N\left(d^{2}\right)}
$$

Sampel yang digunakan dalam penelitian ini adalah 42 orang siswa. Yang didapat dengan menggunakan rumus Propotional Random Sampling. Yusuf (2017:162). 
Teknik pengumpulan data dalam penelitian ini menggunakan angket. Menurut Sugiyono (2018:199). Angket adalah suatu teknik pengumpulan data yang dilakukan dengan cara memberi seperangkat pertanyaan atau pernyataan tertulis pada responden untuk dijawab sesuai dengan diri mereka. Format respon yang digunakan dalam penelitian ini adalah skala likert yaitu digunakan untuk mengukur sikap, pendapat, persepsi seseorang atau sekelompok orang tentang fenomena sosial.

\section{HASIL PENELITIAN DAN PEMBAHASAN}

1. Data Hasil Angket Variabel X (Penggunaan Gadget)

Angket variabel X (Penggunaan Gadget) merupakan angket yang dengan jumlah 15 butir pernyataan dan dibagikan kepada 42orang responden(siswa) sebagai sampel penelitian.

Hasil dari skor penggunaan gadget di SMA Negeri 6 Prabumulih menunjukkan bahwa skor tertinggi adalah 74 dan skor terendah adalah 39 dengan kategori sedang pada penggunaan gadget.

Tabel 1. Penggunaan Gadget

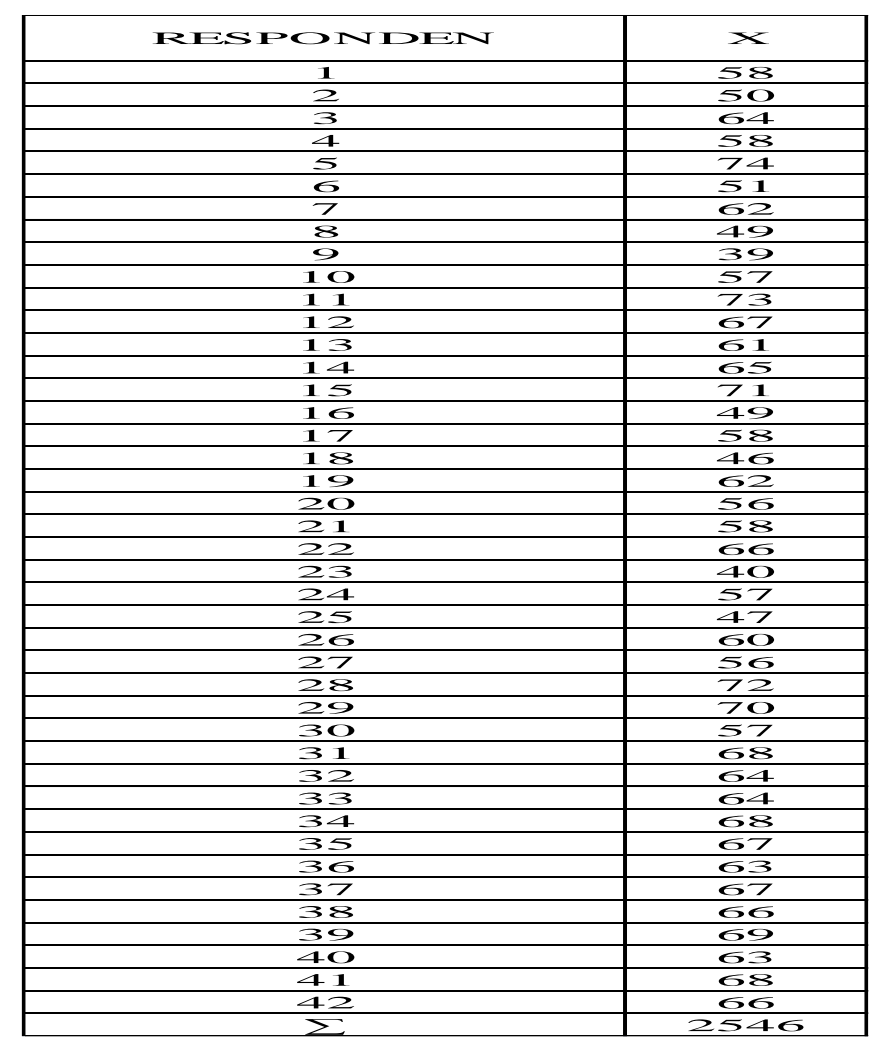




$\begin{array}{ll}\mathrm{N} & : 42 \\ \text { Mean } & : 60,619 \\ \text { Median } & : 62,5 \\ \text { Modus } & : 58 \\ \text { Standar deviasi: } & 8,61919 \\ \text { Maximum } & : 74 \\ \text { Minimum } & : 39\end{array}$

\section{Penggunaan Gadget}

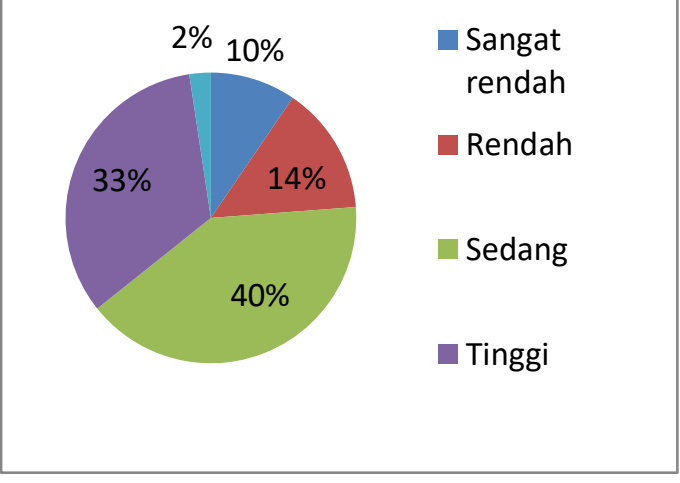

Gambar 2. Penggunaan Gadget

Berdasarkan diagram gambar penggunaan gadget, posisi penggunaan gadget sangat tinggi terdapat 1 orang responden dengan persentase $2 \%$, pada posisi tinggi terdapat 14 orang responden dengan persentase 33\%, pada posisi sedang terdapat 17 orang responden dengan persentase $40 \%$, pada posisi rendah terdapat 6 orang responden dengan persentase $14 \%$, dan posisi sangat rendah terdapat 4 orang responden dengan persentase $10 \%$.

2. Data Hasil Angket Variabel Y (Konsentrasi Belajar)

Angket variabel Y (Konsentrasi Belajar) merupakan angket yang dengan jumlah 13 butir pernyataan dan dibagikan kepada 42 orang responden(siswa) sebagai sampel penelitian.

Hasil dari skor Konsentrasi Belajar menunjukkan bahwa skor tertinggi adalah 63 dan skor terendah adalah 35 dengan kategori sedang pada konsentrasi belajar. 
Tabel 2. Konsentrasi Belajar

\begin{tabular}{|c|c|}
\hline RESPONDEN & $\mathbf{Y}$ \\
\hline 1 & 62 \\
\hline 2 & 46 \\
\hline 3 & 60 \\
\hline 4 & 60 \\
\hline 5 & 61 \\
\hline 6 & 44 \\
\hline 7 & 52 \\
\hline 8 & 45 \\
\hline 9 & 37 \\
\hline 10 & 47 \\
\hline 11 & 62 \\
\hline 12 & 56 \\
\hline 13 & 56 \\
\hline 14 & 54 \\
\hline 15 & 63 \\
\hline 16 & 47 \\
\hline 17 & 63 \\
\hline 18 & 35 \\
\hline 19 & 52 \\
\hline 20 & 49 \\
\hline 21 & 53 \\
\hline 22 & 52 \\
\hline 23 & 36 \\
\hline 24 & 46 \\
\hline 25 & 42 \\
\hline 26 & 56 \\
\hline 27 & 47 \\
\hline 28 & 63 \\
\hline 29 & 61 \\
\hline 30 & 52 \\
\hline 31 & 60 \\
\hline 32 & 63 \\
\hline 33 & 55 \\
\hline 34 & 54 \\
\hline 35 & 57 \\
\hline 36 & 63 \\
\hline 37 & 54 \\
\hline 38 & 57 \\
\hline 39 & 57 \\
\hline 40 & 63 \\
\hline 41 & 54 \\
\hline 42 & 57 \\
\hline$\sum$ & 2253 \\
\hline
\end{tabular}

$\mathrm{N} \quad: 42$

Mean : :53,643

Median : 54,5

Modus : : 63

Standar deviasi: 7,7768

Maximum : 63

Minimum : 35 


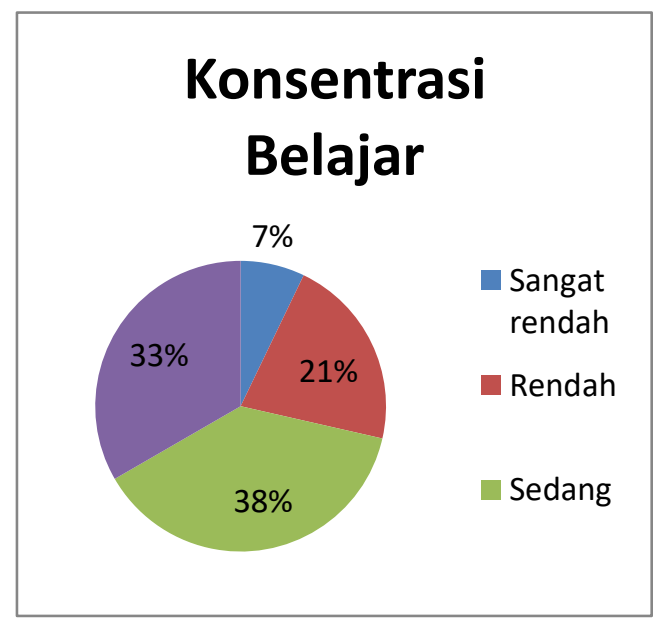

\section{Gambar 3. Konsentrasi Belajar}

Berdasarkan diagram gambar konsentrasi belajar, posisi konsentrasi belajar sangat tinggi tidak ada responden, pada posisi tinggi terdapat 14 orang responden dengan persentase $33 \%$, pada posisi sedang terdapat 16 orang responden dengan persentase 38\%, pada posisi rendah terdapat 9 orang responden dengan persentase $21 \%$, dan posisi sangat rendah terdapat 3 orang responden dengan persentase $7 \%$.

Data penggunaan gadget dan konsentrasi belajar dianalisis dengan menggunakan analisis regresi linier sederhana menggunakan persamaan ý $=a$ + bx yaitu ý $=8,38+0,74 x$. Dari persamaan ini menunjukkan bahwa nilai $a=$ 8,38 yang artinya apabila tidak ada penggunaan gadget pada siswa maka konsentrasi belajar pada siswa akan tetap berkembang karena dipengaruhi faktor lain diluar variabel penelitian ini. Selanjutnya nilai $b=0,74$ yang artinya setiap penambahan satu nilai penggunaan gadget, maka nilai konsentrasi belajar bertambah 0,74 . Kemudian menentukan besar pengaruh variabel $\mathrm{x}$ terhadap variabel y menggunakan rumus korelasi product momentdan mendapat nilair ${ }_{\mathrm{xy}}=0,82$. Kontribusi variabel $\mathrm{x}$ dan variabel $\mathrm{y}$ dengan rumus koefisien determinasi $=\left(\mathrm{r}_{\mathrm{xy}}\right)^{2}=(0,82)^{2}=0,67$ yang bermakna bahwa variabel $\mathrm{y}$ dipengaruhi oleh variabel x sebesar $67 \%$ dan 33\% sisanya dipengaruhi oleh faktor lain diluar dari penelitian ini. 


\section{KESIMPULAN}

Pengujian signifikansi hipotesis menggunakan uji-t (uji satu pihak) diperoleh nilai $\mathrm{t}_{\text {hitung }}=8,63$ sedangkan untuk menentukan nilai $\mathrm{t}_{\text {tabel }}$ dilihat dari distribusi $\mathrm{t}$ dengan $\mathrm{dk}=42-2=40$ dengan $(\alpha)=5 \%$, diperoleh $\mathrm{t}_{\text {tabel }}=1,68385$. Kesimpulan perhitungan kurva diperoleh $t_{\text {hitung }}=8,63>t_{\text {tabel }}$ 1,68385.Hasil penelitian $\mathrm{Ha}$ diterima "Ada Pengaruh PenggunaanGadget Terhadap konsentrasi belajar siswa di SMA Negeri 6 Prabumulih." Penerimaan dan penolakan hipotesis dilihat pada kurva di bawah ini.

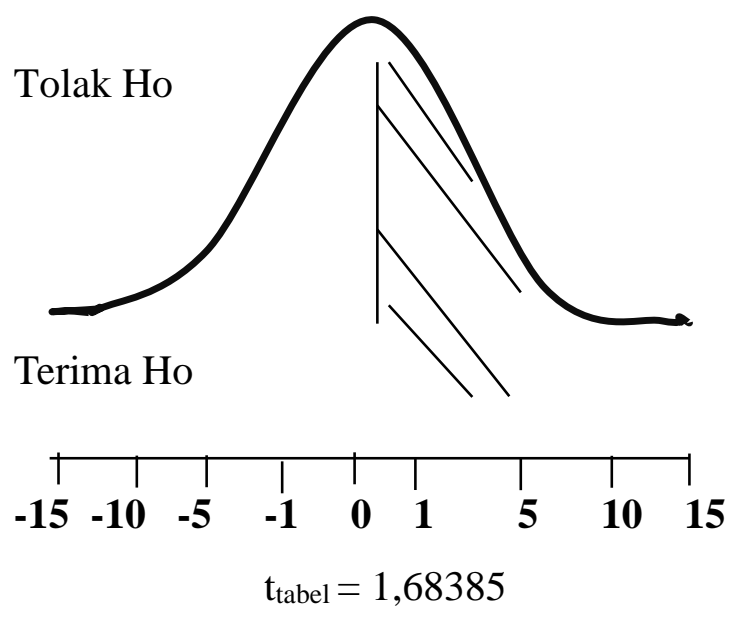

\section{Gambar 4. Kurva Penerimaan dan Penolakan Ho}

\section{DAFTAR PUSTAKA}

Anuggraeni, Aisyah. 2018. Pengaruh Penggunaan Gadget Terhadap Kehidupan Sosial Para Siswa SMA. Jurnal PPKn dan Hukum, Vol. 13 (1), hal. 66.

Audit, dan Sistem Informasi $\quad$ Akuntansi, vol. 3 (1), hal. 5.

Daeng, dkk. 2017. Penggunaan Smartphone Dalam Menunjang Aktivitas Perkuliahan Oleh Mahasiswa Fispol Unsrat Manado. Jurnal Acta Diurna Komunikasi Vol 6 No 1.

Ikawati. 2016. Upaaya Meningkatkan Konsentrasi Belajar Siswa KMS (Kartu Menuju Sejahtera). Menggunakan Konseling Kelompok bagi Siswa. Jurnal: PSIKOPEDAGOGIA. Vol.5, No.1.

Ismail, Fitriani Farinda dan Sumardani. 2019. Pengaruh Informasi Akuntansi dan Pengendalian Internal Terhadap Kinerja Karyawan PT. Beton Elemen Persada. Jurnal Akuntansi 
Manumpil, et al. 2015. Hubungan Penggunaan Gadget Dengan Tingkat Prestasi Siswa di SMA Negeri 9 Manado. Ejoural Keperawatan (e-Kep) Vol. 3 (2), hal. 1.

Nuryana, Purwanto. 2010. Efektivitas Brain GYM dalam Meningkatkan Konsentrasi Belajar Pada Anak.jurnal: Ilmiah Berkala Psikologi Vol. 12, No. 1.

Rahayu. Susanti. 2017. Pengaruh Penggunaan Smartphone Terhadap Pmenuhan Informasi Mahasiswa Prodi S1 Ilmu Perpustakaan Fakultas Adab dan Humaniora UIN Ar-Raniry Angkatan2015.Skripsi:universitas Islam NegeriAr-Raniry Darussalam Banda Aceh.Hal 10.

Setiani Amalia Cahya. 2014. Meningkatkan Konsentrasi Belajar Melalui Layanan Bimbingan Kelompok Pada Siswa Kelas Vi Sd Negeri 2 Karangcegak, Kabupaten Purbalingga Tahun Ajaran 2013/2014. Skripsi Negeri Semarang.Hal 17.

Sugiyono. 2018. Metode Penelitian Pendidikan: Pendekatan Kuantitatif, Kualitatif, Dan $\quad R \& D$. Bandung: Alfabeta.

Syaiful Nur Inayati. 2016. Teknologi Dan Perilaku Sosial Pelajar (Studi Tentang Dampak Penggunaan Smartphone Di Sma Negeri 3 Makassar). Jurnal "Gema Kampus" Ilmu Administrasi, Vol. XI.

Witarsa Ramdhan, dkk. 2018. Pengaruh Penggunaan Gadget Terhadap Kemampuan Interaksi Sosial Siswa Sekolah Dasar.Jurnal PEDAGOGIK.Vol. VI, No. 1.

Taty Fauzi, Melinda P. 2020. Analisis Terhadap Permainan Gadget Anak Usia Balita Dan Upaya Mengurangi Dampak Yang Ditimbulkan Melalui Cerita Pada Anak-anak PAUD Di SU Palembang.

Yusuf, Muri. 2017. Metode Penelitian Kuantitatif, Kualitatif \& Penelitian Gabungan. Kencana: Jakarta.

Zahrah. 2018. Pengaruh Electronic Word Of Mouth Terhadap Keputusan Pembelian Online Pada ProdukFesyen Di

Shopee.Skripsi:Universitas Pendidikan Indonesia, hal.33. 